\title{
SOCIAL MEDIA AND POLITICAL CAMPAIGN Political Communication Strategies in the 2018 East Java Governor Election
}

\author{
Gatut Priyowidodo \& Yustisia D. Sari \\ Petra Christian University \\ Jalan Siwanlankerto 121-131 Surabaya, Indonesia \\ (+62-31) 2983053 \\ Email:gatpr@petra.ac.id
}

\begin{abstract}
Regional election has been carried out simultaneously throughout Indonesia in June 2018. Candidates were competing to draw public attention and sympathy by employing communication via social media. Through social media, candidates can share information on their visions, missions, and major programs. The study is aimed at identifying the political strategies and campaign model employed by the social media campaign team of Syaifullah Yusuf (Gus Ipul) - Puti Guntur Soekarno Putri in the 2018 Governor Election. The study was conducted using netnography method in qualitative/quantitative paradigm. Data collection was carried out through observation of interactive communication on social media, in-depth interview, and literature review. The analysis was conducted using thematic analysis in accordance with the steps in netnography analysis, i.e. by using NVIVO software as the qualitative analysis instrument. The objective of the study was to identify the strategies employed during the campaign for Gus Ipul - Puti Guntur Soekarno Putri. In addition to open campaign and door-to-door campaign to social communities of smaller sizes, the candidate's team also campaigned via social media (Facebook, Instagram, YouTube, and Twitter). The model of campaign employed was in-person campaign and via social media networks. The campaign also included conventional model, i.e. by employing the primary components contained in the delivery and receipt of campaign messages. The campaign model describes that the source (campaign maker) holds a dominant role. $\mathrm{He} /$ she is to build messages aimed at creating changes in the targeted audiences (campaign recipients).
\end{abstract}

Keywords: political campaigns strategies, models of political campaigns, social media netnography, governor election

\section{INTRODUCTION}

Modern political contest requires smart, accurate, and measurable political campaign strategies, and should be willing to adopt the advancement in communication technology. Ignoring the four requirements, it will be very hard to win in a political contest, either in legislative election, President/Vice President election, or Regional Leader Election (Governor, Regent/Mayor). In terms of adoption of information technology in particular, contestants today can no longer rely merely on publications via conventional media (newspaper, television, and radio). Social media platform is another media that requires optimal utilization. Aside from being affordable, social media (Facebook, Instagram, YouTube, Snapchat, and so on) are also known to provide a relatively wide coverage area. 
A number of winning figures in Indonesia's political contest have utilized the excellence of social media as a vote collector instrument. Jokowi - Ahok, in the 2012 DKI Jakarta Governor election, Jokowi - JK in the 2014 President - Vice President Election, and Ridwan Kamil - Uu Ruzhanul's victory (2018) were mainly achieved by their use of social media, especially Twitter and Facebook. The evidence is that, prior to the election, publications around these candidates on social media and online media showed that they were the candidate pair the netizens were mostly talking about. During the vote count by the West Java KPU, the pair collected the highest real votes, amounting to $32.88 \%$. The abovementioned facts provide a strong indication that, in today's age of digital media, the use of social media platforms is highly significant to attract constituent votes.

The rapid growth of information technology, according to a data from APJII (2017), resulted in a high number of penetration of internet users in Indonesia, reaching 143.26 millions of people or equivalent to $54.7 \%$ of Indonesia's total population of 262 millions. Of the said number, the majority of them used smartphones to access the internet. In Indonesia, smartphone ownership rate is $70.96 \%$ in urban areas, $45.42 \%$ in rural urban areas, and $42.06 \%$ in rural areas. Computer, on the other hand, has a slightly lower rate of ownership, i.e. $31.55 \%$ in urban areas, $23.42 \%$ in rural urban areas, and $23.83 \%$ in rural areas. In terms of the distribution of internet users, the Island of Java remains on top with $58.08 \%$, followed by Sumatera $(19.09 \%)$, Borneo (7.97\%), Sulawesi (6.73\%), Bali-Nusa (5.63\%), and Maluku-Papua (2.49\%). This means that in order to attract voters, the candidate pairs, both Gus Ipul - Puti Maharani and Khofifah - Emil Dardak, have identified the profile and number of potential voters they need to persuade into voting for them. This is particularly related to the habit of such potential voters in terms of usage of social media.

According to a 2017 survey by the Association of Indonesian Internet Service Providers (APJII) regarding the duration of social media usage, it is found that most people $(43.89 \%)$ spent between 1 and 3 hours per day to access internet. Some respondents (29.63\%) spent between 4 and 7 hours, while some others $(26.48 \%)$ spent more than 7 hours on the internet. The types of services with most access included chatting applications (89.35\%), social media (87.13\%), search engine (74.84\%), photo/image viewer $(72.79 \%)$, video viewer $(69.64 \%)$, and other applications for different activities. The activity with the least number of accesses was banking activity (7.39\%).

Chatting applications, such as WhatsApp, Line, Facebook, Instagram, Snapchat, and the likes, were the most used social media platforms. This was the reason the two Governor and Vice Governor candidate pairs were very enthusiastic in maximizing their political campaign activities on the two media. In this study, the researcher limited the study to only the candidate pair nominated by the Indonesian Democratic Party of Struggle (PDI-P) and its coalition partners (PKB, Gerindra, and PKS), i.e. Saifullah Yusuf and Puti Guntur Soekarno Putri. Intriguingly, although the four parties were actually two opposing sides-with PDI-P and PKB supporting the Coalition of Jokowi - JK's Administration, while Gerindra and PKS joined in the nongovernment side, the four parties have mutually agreed to nominate the candidate pair for the Governor - Vice Governor election. 
There have been studies on political campaign through media social. A study by Rachmaniar (2018) found that the communication style employed by Ridwan Kamil (RK), then candidate for regional leader, on Instagram was a two-way communication (equalitarian style). This can be seen from the communication and delivery of messages, which was in a two-way direction. The communication was informal and open, where netizens may access the accounts of the regional leader candidates and directly express their opinions, criticisms, ideas, and supports. Similarly, Raenaldy (2017) found that social media in the DKI Jakarta Governor election has strong impacts for competing candidates to gain victory. Another research conducted by Batari (2017) found that the use of social media in the election for Regent of Bulukumba also held a very significant role. In terms of social media advancement, netnography is a very relevant method to employ for deeper exploration of the interactions occuring in virtual world. (Johansson \& Andreasson, 2017).

In reference to the abovementioned phenomena and research results, there is a fact that the research gap lies on the method employed to analyze the significant role of social media in the election of regional leaders. Thus, the problem formulation in this study would be focused on two issues, namely the political campaign strategies and political campaign models in social media. Meanwhile, the research question to discuss would be how campaign strategies and models were employed on social media by Gus Ipul - Puti Maharani's campaign team during the 2018 governor election.

\section{LITERATURE REVIEW}

\section{A. Digital Democracy}

Modern democracy requires fairness in political competition. Anyone has equal access to compete for political positions. This is why during every General Election, there will be numerous candidates taking part in the contest to win the highly limited number of strategic positions. They will take different ways to get themselves elected and to gain public trust. As long as it does not go against the applicable laws, any efforts taken to attract voters can still be tolerated and considered legitimate instruments. Some may rely on conventional means, but some others are embracing the development and advancement of information technology. This is why the concept of democracy is experiencing a contextualization process according to today's condition. Digital age transforms political behaviors into more digitalized behaviors. It also gives rise to digital services, digital payment, as well as the concept of digital democracy. Hague \& Loader (1999) stated that the term digital democracy is preferred here as it brings together the existing electronic technologies through developments in digital data transfer that unleashes the potential of ICT.

As such, it is reasonable that the subsequent dynamics in terms of the mechanism of regional leader election and the way people participate in politics also experience a transformation that is adjusted to digital election format, from the registration of voters, political campaigns, the election itself, the vote count, and the stipulation/announcement of the election results. It is in this context that political campaign as activities aimed at convincing potential voters find the right momentum. Political campaign should be perceived from two aspects, i.e. the meaning as seen 
from the concept-theoretical perspective and the meaning based on the regulation enforced by the government.

\section{B. Campaign Strategies and Political Campaigns}

Roger and Storey (1987, in Berger, Roloff, \& Roskos-Ewolsen, 2011:599) stated that campaign has four essential elements: (1) Campaign aims to create a particular result or impact; (2) campaign is conducted in a relatively large number of individuals; (3) campaign is usually conducted in a predetermined period of time; and (4) campaign is conducted through a series of organized communication activities. Larson (1992, in Heryanto \& Zarkasy, 2012) stated that a campaign is divided into at least three categories. The first is product-oriented campaign, which is generally found in business environment. The second is candidate-oriented campaign, i.e. campaigns that are, as the name suggests, oriented towards candidates and are driven by the desire to obtain political power. The third is ideological campaign, i.e. campaigns that are oriented towards specific objectives, or more commonly known as social change campaign.

The strategy of political marketing in political campaign, according to Newmann (1999:xiii), does not differ greatly from business marketing strategy. He stated that political marketing is the application of marketing principles and procedures in political campaign by various individuals and organizations. Similarly, Hughes and Dunn (2004) also stated that political marketing is a political communication (organizational) function and a set of processing fror creating, communicating, and delivering promises of value to customers, and for managing customer relationships in ways that benefit the political organization and its stakeholders.

Meanwhile, as specified in the provision of Article 1 number 38 of Law Number 7 of 2017 in conjunction with Article 1 number 21 of KPU Regulation Number 23 of 2018, as last amended by KPU Regulation Number 33 of 2018, political campaign is activities conducted by electoral candidates or parties appointed by such electoral candidates to convince voters by offering their visions, missions, programs, and/or image of the candidates.

The definition, when compared to the definition of campaign in the 2014 General Election, has several differences. In the 2014 General Election, in reference to Article 1 number 29 of Law Number 8 of 2012 on Election for the House of Representatives, Regional Representatives, and Regional House of Representatives, general election campaign is defined as activities conducted by electoral candidates to convince voters by offering their visions, missions, and programs.

The question is what differences were there in the campaigns conducted during the 2014 and 2019 elections? According to Tinangon (2019), there are at least two items to consider. The first is related to the subject of the campaign, where in Law Number 7 of 2017, the phrase "or parties appointed by such electoral candidates" has been added to the definition. The phrase means that campaigns can be conducted not only by the electoral candidates themselves, but also by other parties they have appointed for such task. 
The second item is related to the way of convincing voters. In Law Number 7 of 2017, the phrase "and/or image [of the candidates]" has been added to the definition, while previously, Law Number 8 of 2012 only specified the ways of convincing voters, i.e. by offering [the candidates'] visions, missions, and programs cumulatively.

According to Law Number 7 of 2017 in conjunction with Article 1 number 21 of KPU Regulation Number 23 of 2018 on General Election Campaign, as last amended by KPU Regulation Number 33 of 2018, the definition of campaign can be divided into a number of elements, i.e. the subject or implementor of the campaign, objectives of the campaign, and the means employed to achieve the objectives. These campaign elements can also be employed as basic requirements to determine whether or not a particular activity can be classified into electoral campaign. The applicable provisions of the 2019 General Election are rather similar to the campaign regulations for election of Regional Leaders, where the three elements-the implementor, objective, and means-are also required.

\section{Models of Political Campaign}

As the models of political campaigns have similarities to the models of political marketing, Newmans (1994) stated that there are at least 4 models of political campaigns. The first is candidate-focused model, which consists of (a) party concept; (b) product concept; (c) selling concept; and (d) marketing concept.

The second is divided into three categories: (1) marketing campaign or market (voter) segmentation to (a) assess voter needs, (b) profile voters, (c) identify voter segments; (2) candidate positioning, which consists of (a) assessing candidate strengths, (b) assessing competition, (c) targeting segments, and (d) establishing image; (3) strategy formulation and implementation, which consists of (a) the 4 Ps (product/campaign platform), push marketing/grass-root efforts, pull marketing/mass media, and polling/research, and (b) organization development and control.

The third is environmental forces, which consist of (a) technology (computer, television, and direct mails), (b) structural shift (primary convention and rules financial regulations, debates), (c) power broker shifts in influences (candidates, consultants, pollsters, media, political parties, political action committees/groups of interest, voters).

The fourth is political campaign, which consists of (a) pre-primary stage, (b) primary stage, (c) convention stage, and (d) general election stage.

Venus (2004, in Heryanto and Zarkasy, 2012: 85) divided political campaign models into six categories, i.e. componential model, Ostergaard campaign model, the five functional stages development model, Nowak and Warnerryd campaign model, and the diffusion of innovation model.

Componential model is a model that takes the primary components of the process of delivering and receiving campaign messages. In this model, the source (campaign maker) has a dominant role. He/she actively constructs the messages aimed at creating transformation in the campaign receivers. Meanwhile, the Ostergaard 
campaign model stated that campaigns should be based on scientific findings. In other words, it is necessary to firstly identify the problems, find the causal relationship, and find out how the campaign is managed, and to conclude campaign by evaluation on the effectiveness of the programs.

The third is the five functional stages development model, in which campaign goes through five stages, i.e. identification, legitimation, participation, penetration, and distribution.

The fourth is the communicative function model, a model developed by Judith Trend and Robert Friedenberg, which consists of surfacing, primary, nomination, and election.

The fifth is the Nowark and Warneyrd campaign model, in which campaign process starts with the objectives to achieve and ends with the intended effects. In addition, there is interconnectivity among the elements, which consist of the intended effects, competitive communication, communication objects, target population, the channel, the message, the communicator/sender, and the obtained effect.

The sixth is the diffusion of innovation model, in which campaign is carried out in four stages, i.e. information, persuasion, decision-making, and confirmation or reevaluation.

\section{Social Media}

According to Shirky (2008), social media is social software to improve the users' ability to share and cooperate among them and to conduct collective actions beyond institutional or organizational framework. Meanwhile, Mieke and Young (2012) defined social media as a convergence between personal communication for one-on-one sharing and public media for sharing to anyone without being restricted by individual specifities. (Nasrullah, 2017)

Similar to the two statements above, Kaplan and Haenlein (2010, in Utomo, 2013) stated that social media is "A group of internet-based application that builds on the ideological and technological foundations of Web 2.0, and that allows the creation and exchange of user-generated contents." Furthermore, Kaplan and Haenlein also divided the typology of social media into six categories, i.e. (1) collaborative projects, such as Wikipedia; (2) blog; (3) content communities, such as YouTube; (4) social networking sites, such as Facebook and Twitter; (5) virtual social world, such as Second Life; and (6) virtual game world, such as Warcraft. These limitations and typology are certainly useful in differentiating social media from the conventional definition of social media, which is indicated by interpersonal communication and physical contact between individuals.

Gershon (2016: 197-198) stated that social media has seven objectives, i.e. (1) to provide a low-cost platform for enhancing brand awareness; (2) to provide a platform for periodic news and information updates; (3) to provide an opportunity to meet new friends, colleagues, or clients; (4) to make recommendations based on the experiences of friends and acquaintances; (5) to provide opportunities for 
crowdsourcing as well as testing customer reaction or product ideas; (6) to perform an important gate keeping role by highlighting select news and video for general distribution; and (7) to mobilize people to take action by providing information about events, times, and locations.

\section{E. Political Communication}

According to Meadow (1980), political communication is "the exchange of symbols and messages between political actors and institutions, the public in general, and news media that are the products of or have consequences for the political system". Whereas, Perloff (2018) stated that political communication is "the process by which a nation's leadership, media, and citizenry exchange and confer meaning upon messages related to the conduct of public policies".

Arifin (2003:65-98) elaborated the forms of political communication that political communicators may use, as follows: 1) rhetoric or the arts of speaking, debates in court spaces to persuade each other, or speech directed to the public; 2) political agitation operating to mobilize the public into taking part in political movements, either orally or in written, by stimulating and rising public emotion;3) propaganda conducted by politicians or political party cadres with the ability to give suggestions to the public and to create a suggestivity atmosphere; 4) public relation - a two-way relationship established rationally; 5) political campaign, i.e. a form of political communication conducted by persons or groups (organizations) at a particular period of time in order to gain and strengthen political support from the public or voters; 6 ) political lobbying, i.e. face-to-face dialogue (interpersonal communication) engaging informally, but significantly, which typically results in mutual understanding and consensus that will further be strengthened through formal discussion in political meetings or assemblies, which will in turn result in specific decisions and political attitude; 7) mass media, both printed and electronic, can also be effective media of communication. Candidates of regional leaders can use them to share their political messages through publications, encouragements, and other forms of political promotion.

\section{RESEARCH METHOD}

This study is a field research conducted using qualitative netnography method. The data was collected through observation of interactive communication on social media, in-depth interview, and literature review. The analysis was conducted using thematic analysis in accordance with the stages of netnography study analysis, i.e. using NVIVO software as the qualitative analysis device. The stages are presented in the following chart: 


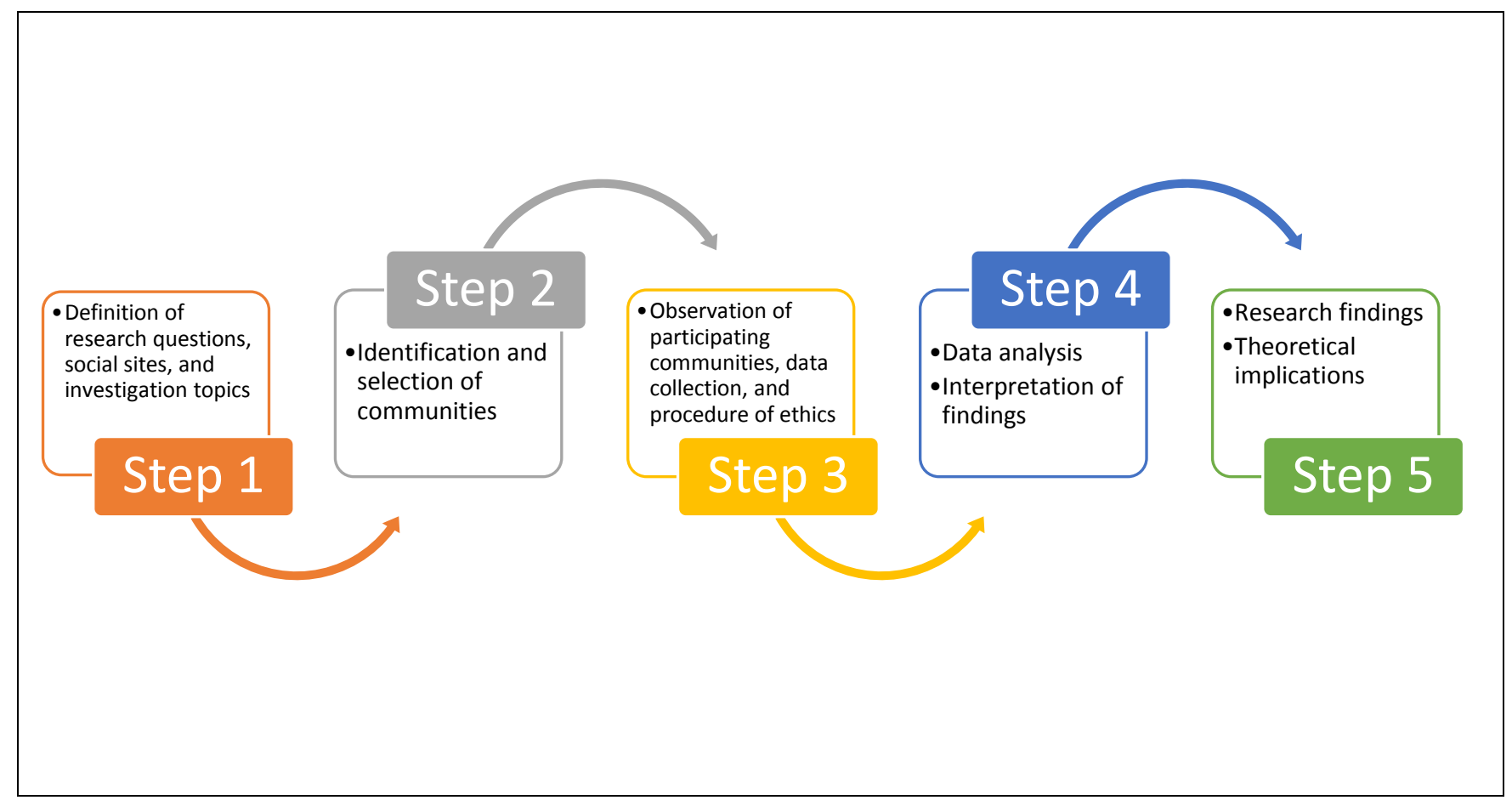

\section{DISCUSSION}

The Regional Leader Election conducted in 2018 was the third direct election within the context of the East Java Governor Election. The first was in 2008, followed by the second election in 2013 (29 August). Governor election with parliamentary mechanism was last carried out in 2003.

The East Java Governor - Vice Governor election carried out on 27 July 2018 presented two candidate pairs - Khofifah Indar Parawansa - Emil Dardak (candidate pair number 1) and Saifullah Yusuf - Puti Guntur Soekarno (candidate pair number 2). Khofifah Indar Parawansa - Emil Dardak was nominated by six political parties, i.e. the Democratic Party, Nasdem, PAN, Hanura, Golkar, and PPP, along with five other supporting parties consisting of PBB, PKPI, PSI, Berkarya Party, and Garuda Party. On the other hand, Gus Ipul - Puti Guntur Soekarno Putri was nominated by PDI-P, PKB, Gerindra, and PKS, and one supporting party, i.e. Perindo.

The emergence of Puti Pramathana Puspa Seruni Paundrianagari Guntur Soekarno Putri as a candidate for Vice Governor to pair with the candidate for Governor, H. Saifullah Yusuf, was actually a political accident. Saifullah Yusuf was initially paired with the Regent of Banyuwangi, Azwar Anas, who was considered quite successful. However, in early 2018, Gus Ipul - Anas' coalition was hit by negative rumors, where some old photos of Anas surfaced and was circulated among the public, showing Anas in a car with a woman. Anas then gradually withdrew himself from the political contest in East Java, and chose to focus on developing Banyuwangi.

As the deadline for the selection and of new Vice Governor candidate to pair with Gus Ipul got closer and the name of the nominee needed to be submitted to KPU, the remaining time window was not sufficient to select from many candidates to substitute 
Anas. The best choice was to directly decide on a nominee. In such condition, the Chairperson of PDI-P immediately decided to nominate Puti Guntur Soekarno as the candidate for Vice Governor.

Gus Ipul - Puti Guntur Soekarno only had limited period that they had to utilize optimally, working hard to convince voters to vote for them as the 2019-2023 Governor and Vice Governor on 27 June 2018. This was why they optimized various media of socialization in order to introduce a relatively new political figure in East Java's political landscape to the voters in East Java. Individually, Saifullah Yusuf (Gus Ipul) had been the Vice Governor twice during Governor Soekarwo's era (2008-2018), thus his figure has been well-known by the public of East Java. On the other hand, people were still trying to get a hold on who Puti Guntur Soekarno Putri was. Aside from the fact that she was the granddaughter of Indonesia's first president, Ir. Soekarno, the public in East Java were left with not much information about who she was.

\section{A. Campaign Strategies on Social Media Employed by Gus Ipul - Puti Guntur Soekarno Putri's Campaign Team in the $\mathbf{2 0 1 8}$ Governor Election}

Four months were clearly a very short time to introduce the figure of Puti Guntur Soekarno Putri to the public of East Java. That was why the campaign strategies chosen were a combination of open campaign and door-to-door campaign to smaller social communities. Based on the stipulation of the General Election Commission (KPU), the campaign period for East Java Governor and Vice Governor election was divided into four sessions: (1) meeting campaigns and distribution of campaign materials, from 15 February to 23 June 2018; (2) open public debate, from 15 February to 23 June 2018; (3) campaign via mass media, from 10 to 23 June 2018; and (4) election silence period and clearing of campaign display materials, from 24 to 26 June 2018.

Puti Guntur Soekarno Putri's lack of track record in East Java's local political landscape forced Gus Ipul - Puti Guntur Soekarno Putri pair to work extra hard. This was very different from their rival - Khofifah Indar Parawansa and Emil Dardak. Khofifah had been nominated twice as the Governor during the previous Governor elections (2008 and 2013), however she lost to Soekarwo. In addition, Khofifah was the former Minister of Social Affairs, who had been known to be relatively active in providing social aids to victims of disaster in East Java. On the other hand, Emil Dardak has also been quite popular in the western region of East Java as he had been the regent of Trenggalek since 2016. The results of the NVIVO analysis can be seen in the image below. 


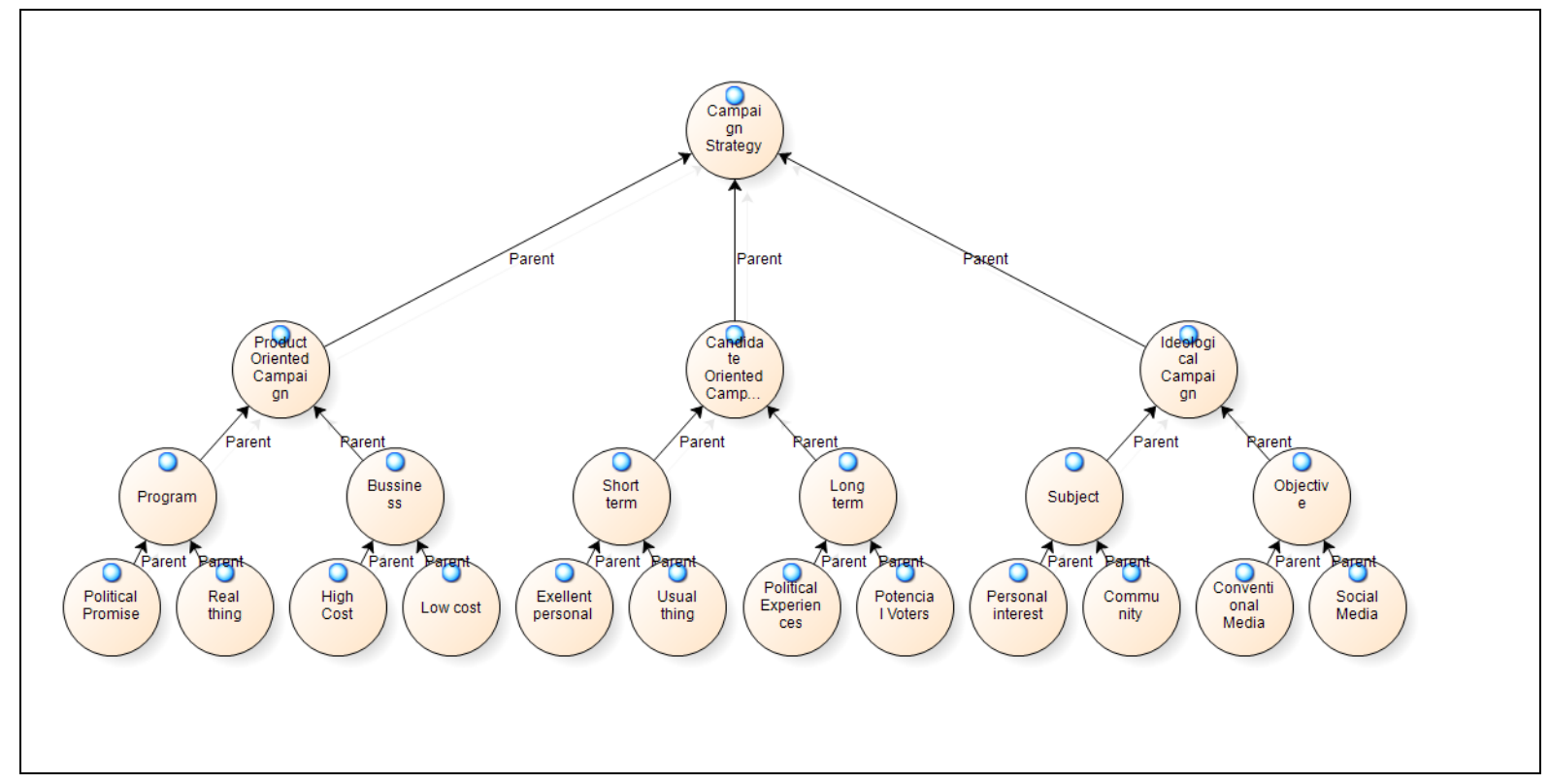

Gus Ipul - Puti Guntur were left with no choice but to maximize the campaign strategies they had at hand. First, they utilized product-oriented campaign, which typically is used in business environment. The strategy was employed by adopting business product marketing principles. In this context, the product was to convince the public by offering a number of programs they would implement should they were elected as the Governor and Vice Governor of East Java for 2019-2023.

The second strategy employed was candidate-oriented campaign, which typically is motivated by the desire to gain political power and thus is usually called political campaign. The strategy was employed by convincing potential voters that the candidate possessed excellent personal qualities as proven by their track record and experience in politics.

The third strategy was ideological campaign, i.e. campaigns oriented towards specific objectives, or more commonly known as social change campaign. The strategy was employed by maximizing the use of existing media, both conventional and social media.

Gus Ipul - Mbak Puti pair 


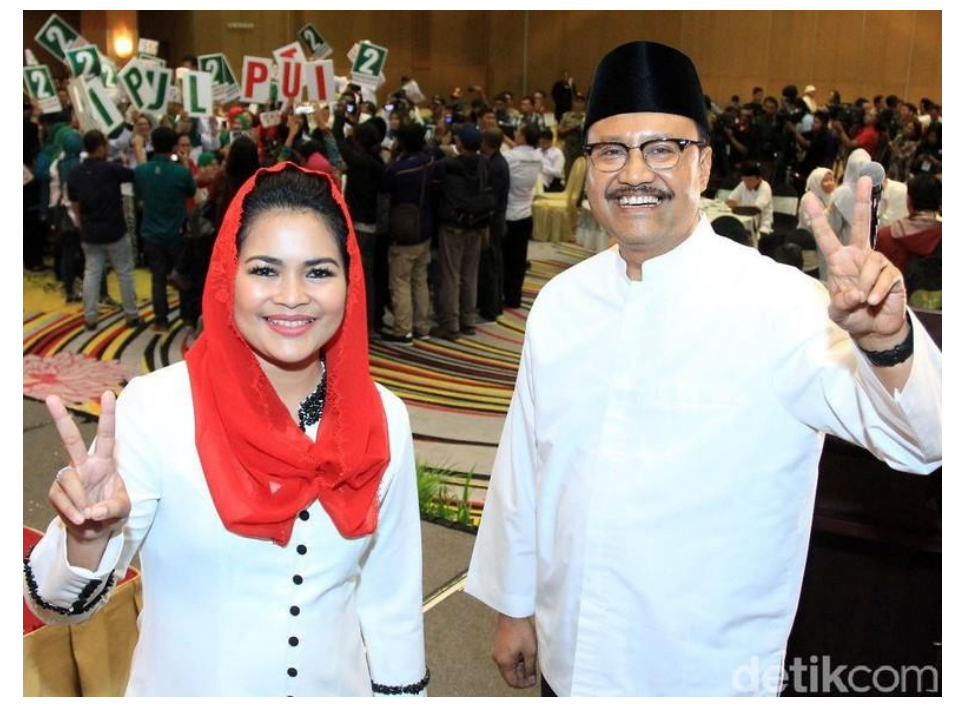

Example of door-to-door campaign

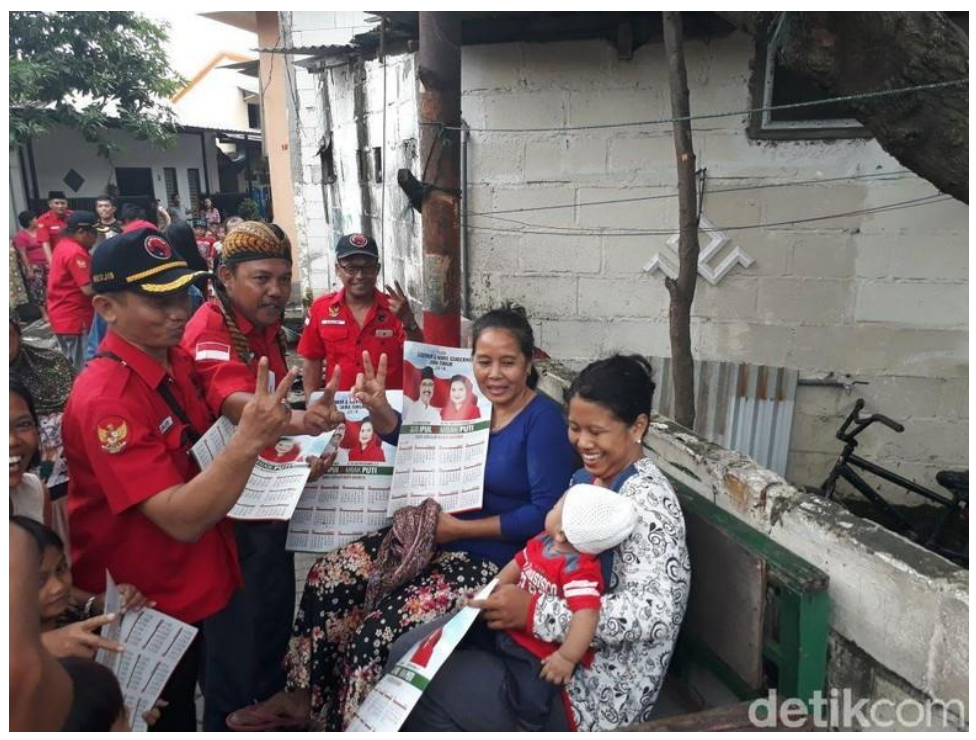

The pair competing in the 2018 East Java Governor election 


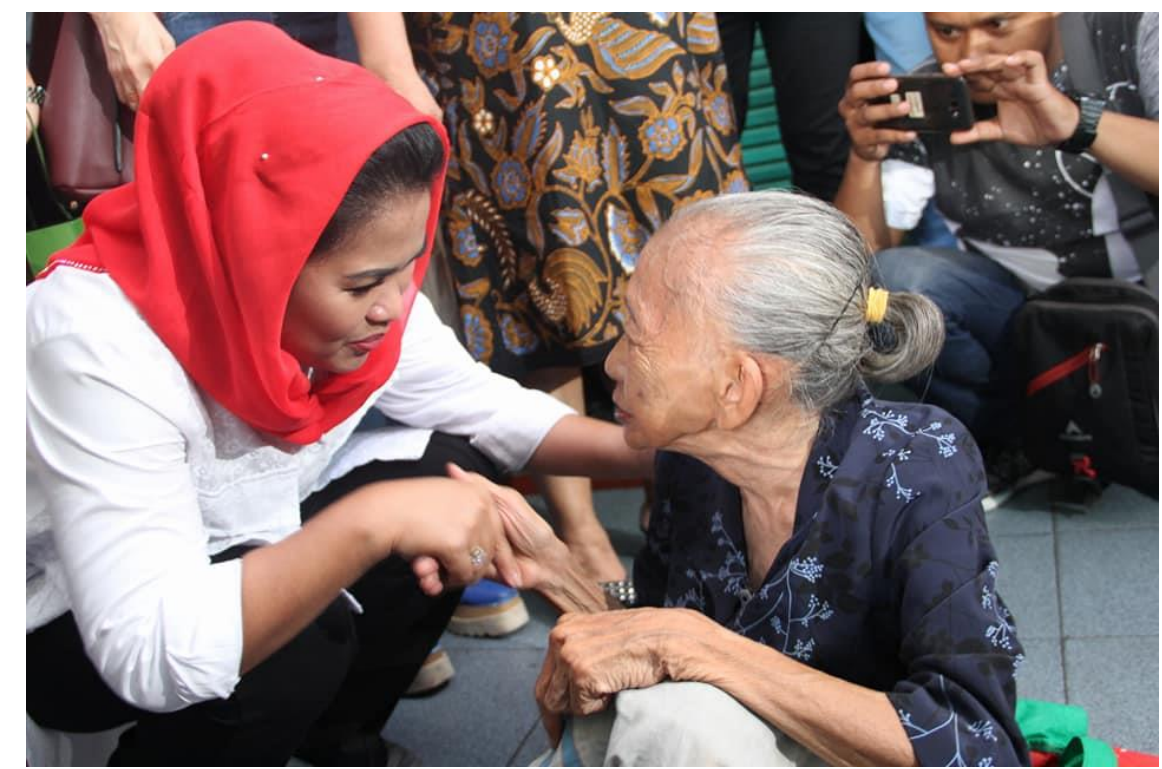

\section{B. Campaign Model on Social Media Employed by Gus Ipul - Puti Maharani's Campaign Team in the 2018 Governor Election}

The campaign model applied was in-person (face-to-face) campaign and mediation via social media, such as Facebook, Instagram, YouTube, and Twitter, which can all be traced via the following addresses: www.putiguntursoekarno.net FANSPAGE: https://www.facebook.com/putigsoekarno/, \#Nomor2UntukJatim, \#KabehSedulur, \#KabehMakmur, \#gusipulmbakputimenang.

All the social media platforms were utilized maximally to attract as many potential voters as possible. However, in more conventional ways, a number of face-to-face meetings were also held to create a balanced channel so that the pair could reach out to more traditional constituents or potential voters who have had no internet access. The campaign area coverage included rural areas, such as Mataraman, Arek, Madura, and Pandhalungan. Mataraman included areas on the western end of East Java, i.e. Ngawi, the District and Municipality of Madiun, Pacitan, Magetan, the District and Municipality of Kediri, Nganjuk, Tulungagung, the District and Municipality of Blitar, Trenggalek, Tuban, Lamongan, and Bojonegoro. Arek included Surabaya and Malang - the center of the Arek culture, which are also two of Indonesia's major cities. On the other hand, potential voters in sub-urban and rural areas would better be approached by direct (face-to-face) meeting with the candidate pair. This was especially true for Madura, as the area required special attention since the pair's rival, Khofifah Indar Parawansa, has been relatively popular around the area.

Other groups of potential voters who would be better approached by direct meeting included those residing in Pandhalungan, which covered the area of Pasuruan, Probolinggo, Situbondo, Bondowoso, Lumajang, and Jember. Geographically, they were located in the eastern end of the Island of Java, but culturally and ethnically, they 
belonged to the Madura ethnicity. This meant that, in terms of religion, they were Moslems and were very obedient to the preachings of their ulammas. The following map shows the division of the province by local community groups

Figure 1 : Local Communiy Group Map

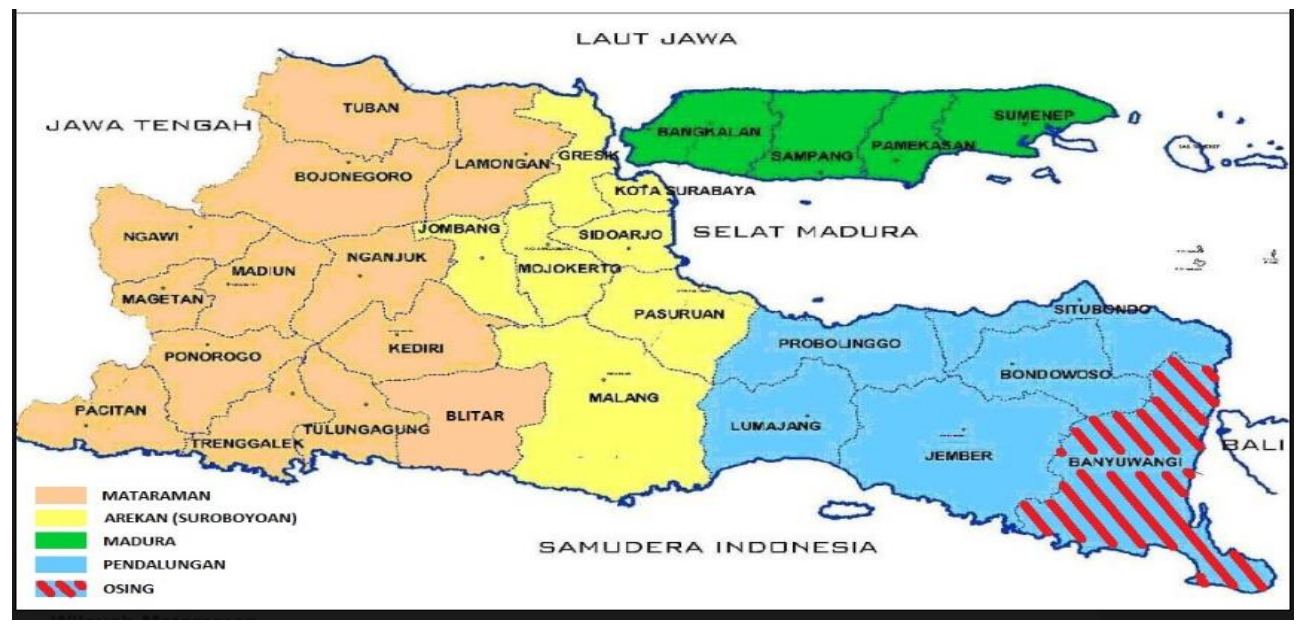

The power of social media to support Gus Ipul - Puti Maharani's electability could generally only be obtained from potential voters in urban areas. This means that, empirically, Gus Ipul and Puti Maharani would need to work extra hard to attract potential voters in non-urban areas. In terms of political investment, Gus Ipul had already had the opportunity to promote himself to the public as he had served as the Vice Governor for two consecutive periods (2009-2014 and 2014-2019). Still, as politics is highly dynamic, everything would need to be utilized maximally.

\section{CONCLUSION}

Based on the analysis above, it can be concluded that the power of social media, through its many platforms, has not been entirely reliable to utilize as the media for gaining victory in the political contest of East Java's governor election. This was, firstly, related to the campaign strategy. Gus Ipul - Puti Maharani have not employed digitalbased campaign strategy optimally. Two main factors underlay such a condition: first, most voters in East Java were traditional ones and dominated by the need for direct (face-to-face) interactive communication; second, information technology infrastructure has not been evenly distributed across East Java, while there was also a considerable gap of digital media literacy between urban and rural voters. In terms of campaign model, Gus Ipul - Puti Maharani still relied on the power of opinion leader, which traditionally remained strong among the public of East Java, in which religious leaders or ulammas were the primary parties to approach in order to attract votes.

\section{ACKNOWLEDGMENT}


The researcher would like to express his gratitude to the Directorate of Research and Community Service (DPRM) of the Ministry of Research, Technology, and Higher Education, who has provided the grant for the PDUPT (Higher Education Basic Research of Excellence) under Research Contract Letter number 008/SP2H/PDUPT/MONO/LPPM-UKP/II/2019. The researcher would also like to show his gratitude to all informants at KPU and Elections Supervisory Agency (Bawaslu) of East Java, Yogyakarta, and West Java, as well as to the Public Relation Department at the Provincial Government of DIY and West Java.

\section{References}

Batari, A.D.W. (2017). Kekuatan Politik Media Sosial Dalam Pemenangan Bupati Dan Wakil Bupati Pada Pemilihan Kepala Daerah Serentak Kabupaten Bulukumba Tahun 2015. Retrieved from http://repository.unhas.ac.id/ handle/123456789/25497

Berger, C.R., Roloff, M.E., \& Roskos-Ewoldsen, D.R. (2011). The Handbook of Communication Science. USA: Wadswoth

Budi, A. (2016). Ini Keunikan yang Hanya dimiliki Masyarakat Jawa Timur. Retrieved from https://www.goodnewsfromindonesia.id/2016/12/27/ini-keunikan-yang-hanya-dimilikimasyarakat-jawa-timur

Gershon, R.A. (2016). Digital Media and Innovation: Management and design strategies in communication, Los Angeles: Sage

Hague, B.N. \& Loader, B.D. (1999). Digital Democracy: Discourse and Decision Making in the Information Age. London: Routledge

Heryanto, G.G. \& Zarkasy, I. (2012). Public Relation Politik. Jakarta: Ghalia Indonesia

Hughes, A. \& S. Dann. (2004). Political Marketing 2006: Direct benefit, Value, and Managing the Voter Relationship, presented at Australian and New Zealand Marketing Academy Conference, Queensland University of Technology, 4-6 December

Johansson, T., \& Andreasson, J. (2017). The Web of Loneliness: A Netnographic Study of Narratives of Being Alone in an Online Context. Social Sciences, 6(3), 101. Retrieved from https://doi.org/10.3390/socsci6030101

Kozinets, R.V. (2013). Netnography Doing Etnographic Research Online. London: Sage

Nasrullah, R. (2017). Media Sosial. Bandung: PT Remaja Rosdakarya

Newmann, B.I. (1999). The Mass Marketing of Politics. Thousand Oaks, CA: Sage

Perloff, R.M. (2018). The Dynamics of Political Communication: Media and Politic in a Digital Age. London: Taylor and Francis Ltd.

Rachmaniar, R.A. (2018). Gaya Komunikasi Calon Kepala Daerah Menjelang Pilkada Pada Media Sosial Instagram. SOSIOGLOBAL 2(2), 49-57

Raenaldy, A., Erviantono, T., \& Bandiyah. (2017). Hubungan antara Media Sosial terhadap Peluang Kemenangan Pasangan Calon Gubernur DKI Jakarta Pada Pilkada 2017 (Studi Wilayah Jakarta Utara). Retrieved from https://ojs.unud.ac.id/index.php/politika/article/view/33205/20053 
Tinangon, M.Y. (2019). Anatomi Definisi Kampanye 2019. Retrieved from https://kpu.go.id/post/read/2019/7383/Anatomi-Definisi-Kampanye-Pemilu-2019

Utomo, W. P. (2013). Menimbang Media Sosial dalam Marketing Politik di Indonesia: Belajar dari Jokowi-Ahok di Pilkada DKI Jakarta 2012. Jurnal IImu Sosial Dan IImu Politik, 17(1), 67-84

Rachmaniar, R.A. 2018. Gaya Komunikasi Calon Kepala Daerah Menjelang Pilkada Pada Media Sosial Instagram. SOSIOGLOBAL 2(2), 49-57

Raenaldy, A., Erviantono, T., \& Bandiyah. 2017. Hubungan antara Media Sosial terhadap Peluang Kemenangan Pasangan Calon Gubernur DKI Jakarta Pada Pilkada 2017 (Studi Wilayah Jakarta Utara). Retrieved from https://ojs.unud.ac.id/index.php/politika/article/view/33205/20053

Batari, A.D.W. 2017. Kekuatan Politik Media Sosial Dalam Pemenangan Bupati Dan Wakil Bupati Pada Pemilihan Kepala Daerah Serentak Kabupaten Bulukumba Tahun 2015. Retrieved from http://repository.unhas.ac.id/ handle/123456789/25497

Johansson, T., \& Andreasson, J. 2017. The Web of Loneliness: A Netnographic Study of Narratives of Being Alone in an Online Context. Social Sciences, 6(3), 101. Retrieved from https://doi.org/10.3390/socsci6030101

Roger \& Storey (19870 in Berger, C.R., Roloff, M.E., \& Roskos-Ewoldsen, D.R. 2011. The Handbook of Communication Science. USA: Wadswoth

Larson, (1992 in Heryanto, G.G. \& Zarkasy, I. 2012. Public Relation Politik. Jakarta: Ghalia Indonesia

Newmann, B.I. 1999. The Mass Marketing of Politics. Thousand Oaks, CA: Sage

Hughes, A. \& S. Dann. 2004. Political Marketing 2006: Direct benefit, Value, and Managing the Voter Relationship, presented at Australian and New Zealand Marketing Academy Conference, Queensland University of Technology, 4-6 December

Tinangon, M.Y. 2019. Anatomi Definisi Kampanye 2019. Retrieved from https://kpu.go.id/post/read/2019/7383/Anatomi-Definisi-Kampanye-Pemilu-2019

Newmann, B.I. 1999. The Mass Marketing of Politics. Thousand Oaks, CA: Sage

Venus (2004 in Heryanto, G.G. \& Zarkasy, I. 2012. Public Relation Politik. Jakarta: Ghalia Indonesia

Utomo, W. P. 2013. Menimbang Media Sosial dalam Marketing Politik di Indonesia: Belajar dari Jokowi-Ahok di Pilkada DKI Jakarta 2012. Jurnal IImu Sosial Dan IImu Politik, 17(1), 67-84

Gershon, R.A. 2016. Digital Media and Innovation: Management and design strategies in communication, Los Angeles: Sage

Priyowidodo, G., Swestin, G., \& Nur V.T. 2014. The Faces of Conflict in a Political Organization: The case of the Indonesia Democracy Party of Struggle (Partai Demokrsi Indonesia Perjuangan PDI-P). Mediterranean Journal of Social Sciences, 5(19), 608.

Retrieved from http://www.mcser.org/journal/index.php/miss/article/view/4296 DOI: $10.5901 / \mathrm{mjss} .2014 . v 5 n 19 p 608$

Priyowidodo, G.2016.. Politics and Organization in Opposition: Patterns of Communication and Decision Making in Parti Keadilan Rakyat (The People's Justice Party) of Malaysia. The Social Sciences, $11 \quad$ (2) : 113-119. http://medwelljournals.com/abstract/?doi=sscience.2016.113.119

DOI: 10.3923/sscience.2016.113.119

Kozinet, R.V. (2013). Netnography Doing Etnography Research Online, London: Sage 